\section{Research Article}

(C) 2021 Devos et al..

This is an open access article licensed under the Creative Commons Attribution-NonCommercial 4.o International License (https://creativecommons.org/licenses/by-nc/4.o/)

\title{
The Application of the Simulation Method in the in Foreign Language Teaching in Higher Education Institutions, the Cognitive Linguistic Approach
}

\author{
Anastasiia Oleksandrivna Devos ${ }^{1}$ \\ Iryna Oleksiivna Torbenko ${ }^{2}$ \\ Tetiana Volodymyrivna Doroshenko3 \\ Viktoriia Volodymyrivna Revenko ${ }^{4}$ \\ Andrii Volodymyrovych Shuhaiev5
}

\author{
${ }^{1}$ Institute of Philology, Borys Grinchenko Kyiv University, Kyiv, Ukraine \\ ${ }^{2}$ International Medical Faculty, Donetsk National Medical University, Lyman, Ukraine \\ ${ }^{3}$ State University of Intellectual Technologies and Communications, Odesa, Ukraine \\ ${ }^{4}$ Faculty of Foreign Languages, Kryvyi Rih State Pedagogical University, Kryvyi Rih, Ukraine \\ 5Department of English Philology and Translation, Zhytomyr Ivan Franko State University, Zhytomyr, Ukraine
}

DOI: https://doi.org/10.36941/jesr-2021-0072

\section{Abstract}

This article presents the results of the research aimed at proving the efficiency of using the simulation method in combination with the cognitive linguistic approach in teaching students a foreign language. The experimental group students studied the foreign (English) language course during the semester of the 2019-2020 academic year using simulations. The methodology consisted of the performance of roles by the students who actively interacted for the implementation of assigned tasks. Kravchenko's cognitive linguistic algorithm was used to develop the skills of English grammar. This allowed us to establish the similarities between the temporal forms of English and Ukrainian words in discourse. The efficiency was evaluated through the test, developed by the author based on the exercises from the book by Holitsynskyi. Diagnostics of the students' level of motivation to learn a foreign language using simulations and cognitive linguistic approach was performed with the help of the Self-Assessment Form Student test, described in the EU manual. The statistical significance of the study results was established using Pearson's $\chi_{2}^{2}$ test. The correlation between the factor and resultant characteristics was established using Tschuprow's contingency coefficient. This was revealed through the methodology of applying the cognitive linguistic approach regarding the training of the skills in choosing the tense forms of a verb in English and the method of simulations in the development of language competencies of the business foreign language. It was found that the proportion of experimental group students with a high and sufficient level of success in learning a foreign language doubled, exceeding the same indicator in the control group. The total number of students with very high, high and average levels of development of skills in choosing the tense forms of the verb in English increased by $36 \%$. The influence of the skills of choosing the tense forms of the verb on the development of the skills of using grammatical structures found in the process of the simulation was recorded. The results of the study can be applied in teaching students a foreign language in the institutions of higher and secondary education, as well as in the system of post-graduate education. The problems of individual students' passivity regarding their participation in simulations, failure to use a foreign language in group work require further research.

Keywords: students, cognitive linguistic approach, simulation approach, foreign language, language competencies and the tense forms of verbs 


\section{Introduction and Literature Review}

One of the most critical problems of teaching students foreign languages in higher educational institutions is the search and substantiation of effective didactic methods. Traditional lectures, seminars and practical classes can't meet the demands of students seeking greater mobility, continuous improvement and expanding access to foreign language professional information. At present, there are a large number of methods and technologies, among which it is worth highlighting the simulations, which are still insufficiently studied and require experimental testing.

In interpreting the simulation as a method of teaching a language, we will be based on the interpretation of Jones (2013), who defined simulation "as the reality of functions in a simulated and structured environment". In other words, it refers to recreating or simulating the functions that students have to perform in real-life situations and professional activities in a foreign language. In other words, the simulation can be defined as a way of creating an enriched communicative environment (a reflection of reality) in which students take on functional roles such as various duties and responsibilities and work together as team members to make decisions and find solutions to problems in situations closely related to the real professional activities. To achieve this goal, they must communicate in a target (foreign) language, adapting to real professional and behavior. The effectiveness of the simulations is largely ensured by the immersion effect, i.e. by immersing oneself in the simulated situation. Other advantages of simulations include a significant increase in independence and the motivation of students, reducing the level of anxiety of making a mistake plus the development of teamwork skills. Teaching a foreign language through simulations allows students to experiment with new vocabulary and structures, combines language learning and the development of professional competencies, promotes identification with the target culture and reduces the language interference, provides students with the practical confidence of "I did it, so I can do it" (rather than the kind of "I read it, so now I know it" confidence), it breaks down barriers in the " teacher to student" relationship (students control their activities within the simulation), allows teachers to unobtrusively control the progress and participation of students in the simulation (Methods, 2013).

Given the practice-oriented nature of simulation, it can be considered as one of the methods of experiential learning, the theoretical basis of which was developed by Kolb and Kolb (2017). The essence of the concept lies in the fact that the assimilation of the information in the learning process occurs through the particular experience and abstract conceptualization resulting in four stages of learning, from the experience (first stage) to the observation (second stage) followed by reflection, abstraction and theoretical generalization (third stage) and, finally, experimental testing and application in practice of the obtained knowledge. The ideas of Kolb and Kolb (2017) were further developed by such researchers as Hawk and Shah (2007), Li (2019) and Li et al. (2016), Beames and Brown (2016), etc.

The significant didactic potential of simulations attracts contemporary researchers and teachers of foreign languages, showing the didactic advantages of this method (Chergui, 2016; Odo C. \& Odo A., 2016; McKim, 2017; Oskina, 2017; Sharifi et al. 2017; Vlachopoulos \& Makri, 2017; Lutfi et al, 2018; Shcherbakova, 2018; Uguma \& Obiekezie, 2018; Angelini \& García-Carbonell, 2019b).

At the same time, the simulation method has certain disadvantages, under certain conditions it can lead to incorrect speech, distorted understanding and neglect of new vocabulary and grammatical structures. In a group simulation for the unmotivated students or the students without sufficient speech practice, there is an opportunity to "hide behind the backs" of their more trained colleagues. It is worth noting that simulation is quite a time-consuming teaching method as it requires a lot of time to prepare, conduct and do final analysis. Besides a basic level of foreign language proficiency, simulations require students to have a certain level of professional training. (Methods, 2013).

Practice shows that the best results can be achieved through the application of the cognitive linguistic approach to the teaching of a foreign language in conjunction with simulations and other didactic methods. In this regard, the task was to substantiate the feasibility of the simulations and assess their didactic effectiveness in teaching students a foreign language in higher education institutions. 


\section{Methods}

The study conducted experimental testing of the effectiveness of the cognitive linguistic approach and the application of the simulation method in teaching students a foreign language in higher educational institutions. The volume of the general population was 145 students in the fourth course of specialization 073 "Management", which allowed to ensure a sample of 105 students at the level of $95 \%$ confidence probability and with the $5 \%$ confidence interval of error. Using the method of randomization, an experimental group (EG) of 52 people and a control group (CG) of 53 people were gathered. The groups were equalized in terms of gender and age, indicators of success in learning a foreign language. The experiment was carried out according to the scheme "C-post with the control group". The EG students studied a foreign (English) language course during the semester of the 20192020 academic year using simulations ("King's Nuts", "The Deep Pockets", "Building Airplanes", "Lost at Sea"). The methodology of the preparation and conducting the simulations consisted of three stages. The task of the first stage was to familiarize the students with the situation and explain what significance it has for their professional development. To structure the functions of the students as participants in the simulation, situation cards with descriptions of the relevant roles, functions, and tasks were prepared. The necessary vocabulary to prepare for communication in a foreign language was also provided. The main stage of the simulation took place in the classroom and consisted of students performing roles that actively interacted for the implementation of the assigned tasks. Communication during the simulation was in English. At the same time, a video recording was carried out. The final stage included debriefing and discussion of the simulation results. Particular attention was paid to established language skills and to errors that occurred during the simulation. If necessary, the teacher provided grammatical explanations. This made it possible to determine the ways and tasks for further improvement of the students' language competencies. For the development of English grammar skills, the method of Kravchenko (2013) was applied, which is based on the cognitive theory of time and type (Figure 1). The algorithm allows establishing the similarity between the tense forms of English and Ukrainian verbs, which simplifies and accelerates the formation of the skill of correctly choosing a particular form of the verb in the discourse. The use of this method by the author and his students and colleagues for 20 years in educational institutions of various levels has shown its high efficiency, which far exceeds the existing traditional methods.

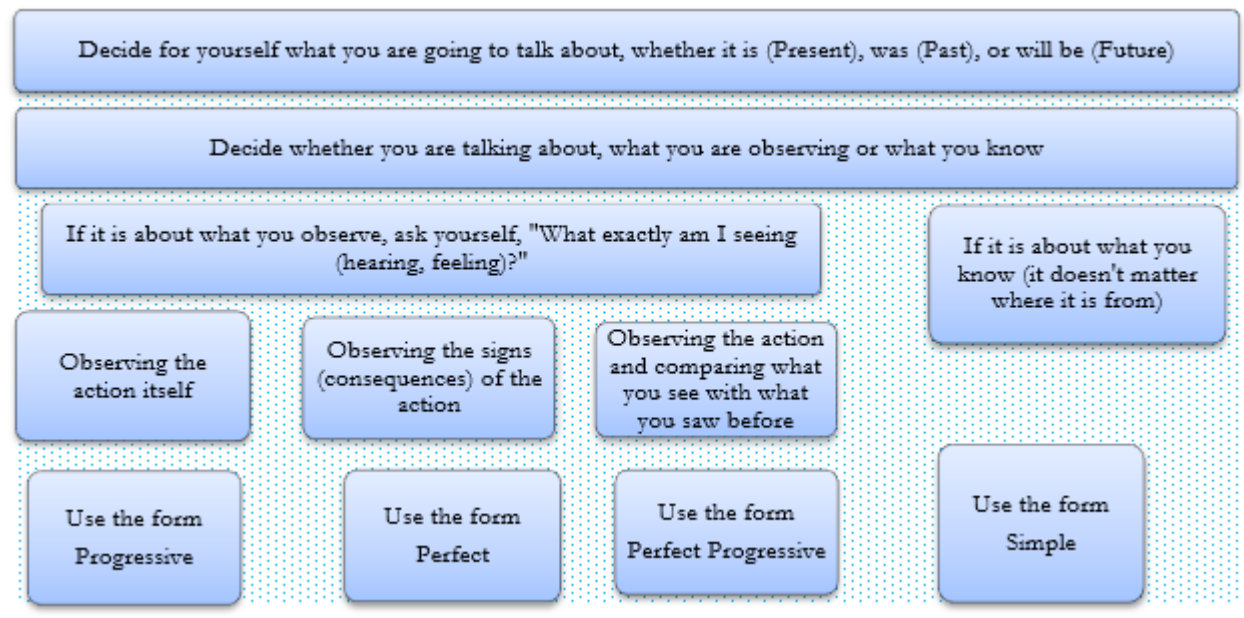

Figure 1: Algorithm for choosing the tense form of a verb (Kravchenko, 2013) 
Verb forms were studied by performing exercises from the exercise book by Holitsynskyi and Holitsynska (2019) according to the developed algorithm in three tenses (present, past, and future) as well as within three sentences (statement, question and negation). The results of the exercises were corrected through the comprehension of the essence of the transmitted message.

In the CG the lessons of the foreign language (as well as English) language were conducted according to the traditional methodology (without using the method of simulations and cognitive linguistic approach).

To assess the effectiveness of the given methodology, diagnostics of the mentioned skills were carried out twice (before and after the experiment) by using the test developed based on exercises from the exercise book by Holitsynskyi and Holitsynska (2019, pp. 220-222). The procedure was aimed at revealing the level of knowledge and skills to correctly apply the tense form of English verbs. It consisted of performing tasks that involved replacing the infinitive of verbs in the parentheses with the desired tense form of the verbs in the sentences. A total of 99 tasks were included in the test, of which correct performance from 89 to 99 of them corresponded to a very high level, from 74 to 88 a high level, from 59 to 73 an intermediate level, from 34 to 58 a low level, and from 1 to 33 a very low level of performance.

The ECTS system (European Commission, 2020) was used to establish the homogeneity of the experimental and control groups, as well as changes in the success of mastering a foreign language course in EG. According to this system, the high level of success was correlated with the grade "A" (90 to 100 points), a sufficient level was determined by grades "B" and " $\mathrm{C}$ " (75 to 89 points), the average level corresponded to grades "D" and "E" (6o to 74 points), the low level was determined with grades "FX" ( 36 to 59 ) and "F" (1 to 35 points). The assessment procedure was conducted by an examination committee consisting of the head of the "Foreign Language" department and two teachers.

Diagnostics of the level of students' motivation to learn a foreign language using simulations and the cognitive linguistic approach was carried out by using the test (Appendix) given in the manual on the operation of simulations in the learning of foreign languages, prepared within the project of the European Commission (Methods, 2013, pp. 31-32).

\section{Results}

In the situation "before the experiment" a "zero" data check-up in the EG and CG was carried out on such features as the performance indicators in a foreign language, motivation to learn a foreign language and the ability to use the tense forms of English verbs. The performance data are shown in Table 1.

Table 1: The performance indicators of the students learning a business foreign language ("zero" check-up)

\begin{tabular}{|l|c|c|c|c|}
\hline \multirow{2}{*}{ Levels of learning success* } & \multicolumn{2}{|c|}{ EG } & \multicolumn{2}{c|}{ CG } \\
\cline { 2 - 5 } & Persons & $\%$ & Persons & $\%$ \\
\hline High & 3 & 6,0 & 4 & 8,0 \\
\hline Sufficient & 10 & 20,0 & 9 & 17,0 \\
\hline Average & 29 & 56,0 & 28 & 53,0 \\
\hline Low & 10 & 18,0 & 12 & 22,0 \\
\hline Total: & 52 & 100 & 53 & 100 \\
\hline
\end{tabular}

${ }^{*}$ According to ECTS

The calculation of the data in the Table 1 showed that the statistical value of the $\chi_{2}$ criterion is 0.385 , not exceeding its critical value (at the significance level of $\mathrm{p}<0.05$ it is 7.815 ), which gives reasons to say that there are no significant differences in the groups for this indicator. Totally in the groups, the majority of students have an average ( 53 to $56 \%$ ) and low (18 to $22 \%$ ) levels of foreign language proficiency, while the sufficient and high levels are found in about a quarter ( 25 to $26 \%$ ) of students. 
According to the task of the study before the experiment, a check-up of the skills of correctly choosing the tense forms of the verb in English was made, the results of which are presented in Table 2.

Table 2: Levels of development of students' skills in choosing the tense forms of the verb (a "zero" check-up)

\begin{tabular}{|l|c|c|c|c|}
\hline \multirow{2}{*}{ Levels* } & \multicolumn{2}{|c|}{ EG } & \multicolumn{2}{c|}{ CG } \\
\cline { 2 - 5 } & Persons & $\%$ & Persons & 4,0 \\
\hline Very high & 2 & 4,0 & 2 & 21,0 \\
\hline High & 11 & 21,0 & 11 & 31,0 \\
\hline Average & 19 & 37,0 & 17 & 21,0 \\
\hline Low & 10 & 19,0 & 11 & 23,0 \\
\hline Very Low & 10 & 19,0 & 12 & 100 \\
\hline Total: & 52 & 100 & 53 & 20 \\
\hline
\end{tabular}

* Developed by the author based on the exercises of Holitsynskyi and Holitsynska (2019, pp. 220-222)

The analysis of the data in Table 2 shows that the distribution of students according to test results in the groups is almost the same, with $4 \%$ of students in each group having a very high level and $21 \%$ having a high level. The distribution according to other levels showed insignificant deviations in the groups. The calculation showed that the empirical value of $\chi^{2}$ criterion does not exceed its critical value: $\chi^{2}=0.331<\chi 2 \mathrm{kr}=9.488$ at the significance level of $\mathrm{p}<0.05$.

By the end of the academic semester, based on the results of studying a foreign language course according to the experimental methodology a re-diagnostics of learning success was carried out in the EG. The results of the "final" check-up in comparison with the indicators of the "zero" check-up in the EG are shown in Figure 2. Thus, the number of students with a high level increased over three times, $19.0 \%$ ("final" check-up) against 6.0\% ("zero" check-up). There was also an increase of almost 2.5 times the number of students with a sufficient level of $48.0 \%$ ("final" check-up) as opposed to 6\% ("zero" check-up). On the other hand, the number of average level students almost halved (29\% vs. 56\%) and the number of students with low academic performance decreased by 4.5 times $(4.0 \%$ vs. $18.0 \%$, respectively). The calculations showed that the empirical value of the $\chi_{2}$ criterion significantly exceeded the critical value of this criterion: $\chi^{2} \mathrm{em}=15.838>\chi_{2} \mathrm{cr}=11.345$ at the level of statistical significance of $\mathrm{p}<0.01$. This means that the performance indicators in the EG have significantly changed.

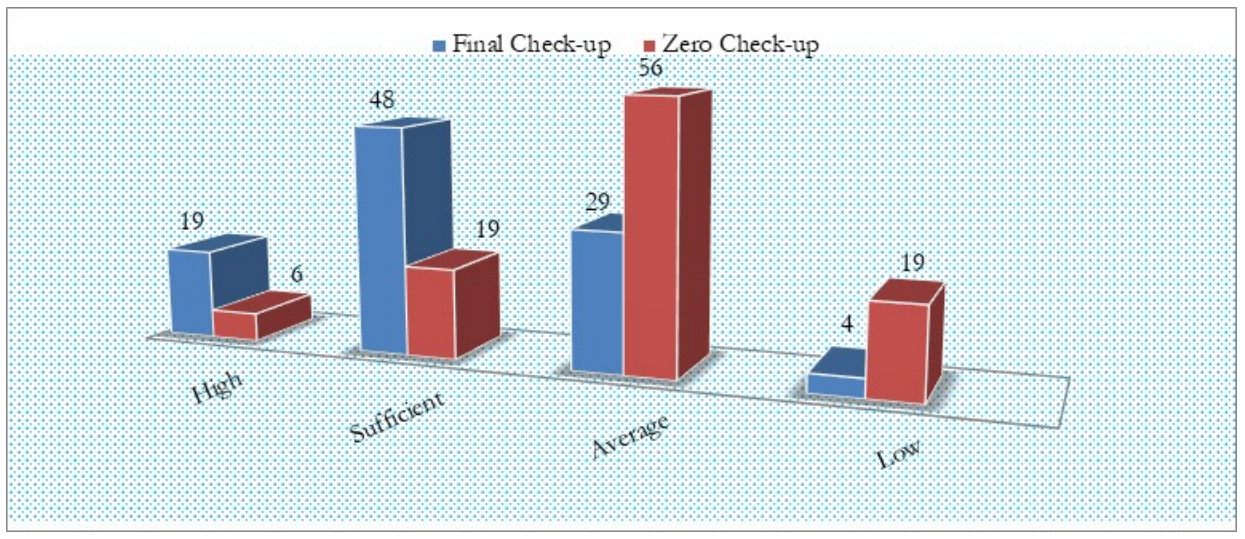

Figure 2: Comparison of the performance indicators of the students learning a business foreign language ("zero" check-up) and after ("final" check-up) the experiment, in \% 
Along with the analysis of changes of the learning success under the influence of simulations in the EG, the comparison of this indicator in the EG and the CG after the experiment was carried out. The relevant calculations showed that in the EG the proportion of students with a high level was over twice as high as in the CG, and the proportion of the EG students with a sufficient level was almost 2.5 times higher than the corresponding proportion of students in the CG. There was also a significant decrease in the proportion of students with an average and low level of success compared to the CG, in which these indicators remained almost unchanged. This pointed out convincingly testifies to the positive impact of applying the simulation method on the success of the students' learning of business foreign language in higher education institutions.

Besides the success of learning a language, the final check-up of the skills of choosing the tense forms of the verb was also carried out in the EG students, the results of which are shown in Table 3.

Table 3: The changes in the development of the EG students' skills of choosing the tense forms of the verb in English

\begin{tabular}{|l|c|c|c|c|}
\hline \multirow{2}{*}{ Levels* } & \multicolumn{2}{|c|}{ EG ("final” check-up) } & \multicolumn{2}{c|}{ EG ("zero" check-up) } \\
\cline { 2 - 5 } & Persons & $\%$ & Persons & $\%$ \\
\hline Very high & 12 & 23,0 & 2 & 4,0 \\
\hline High & 24 & 46,0 & 11 & 21,0 \\
\hline Average & 12 & 23,0 & 17 & 31,0 \\
\hline Low & 3 & 6,0 & 11 & 21,0 \\
\hline Very Low & 1 & 2,0 & 12 & 23,0 \\
\hline Total: & 52 & 100 & 53 & 100 \\
\hline
\end{tabular}

*Developed by the author based on the exercises of Holitsynskyi and Holitsynska (2019, pp. 220-222)

According to the data in Table 3, the application of the cognitive linguistic approach resulted in a tangible improvement in the development of the skills of choosing the tense forms of the verb in English in the EG. According to the final check-up, the total proportion of students with very high, high and average levels of development of these skills was $92 \%$, while before the experiment this indicator was recorded at the level of $56 \%$.

A visual representation of the development of the skills of choosing the tense forms of the verb in English of the EG students is given in Figure 3.

Thus, the presented data provide convincing evidence of the effectiveness of the application of the cognitive linguistic algorithm in the development of skills in choosing the tense forms of the verb in English.

In the process of the study in the final check-up with the help of the test (Appendix) the language competencies of a business foreign language that were developed in the process of using simulations were assessed, namely, the ability to cooperate in the group work (question no. 1), to use the foreign language, communicating with other group members (question no. 2), the ability to assert their opinions (question no. 3), to explain their decisions (question no. 4), the ability to make suggestions to the group (question no. 5), to ask others to explain things they do not understand (question no. 6), to accomplish the task by communicating with their colleagues (question no. 7). Two other questions concerned the sufficiency of vocabulary (question no. 8) and the ability to use grammatical structures to express their thoughts correctly (question no. 9). 


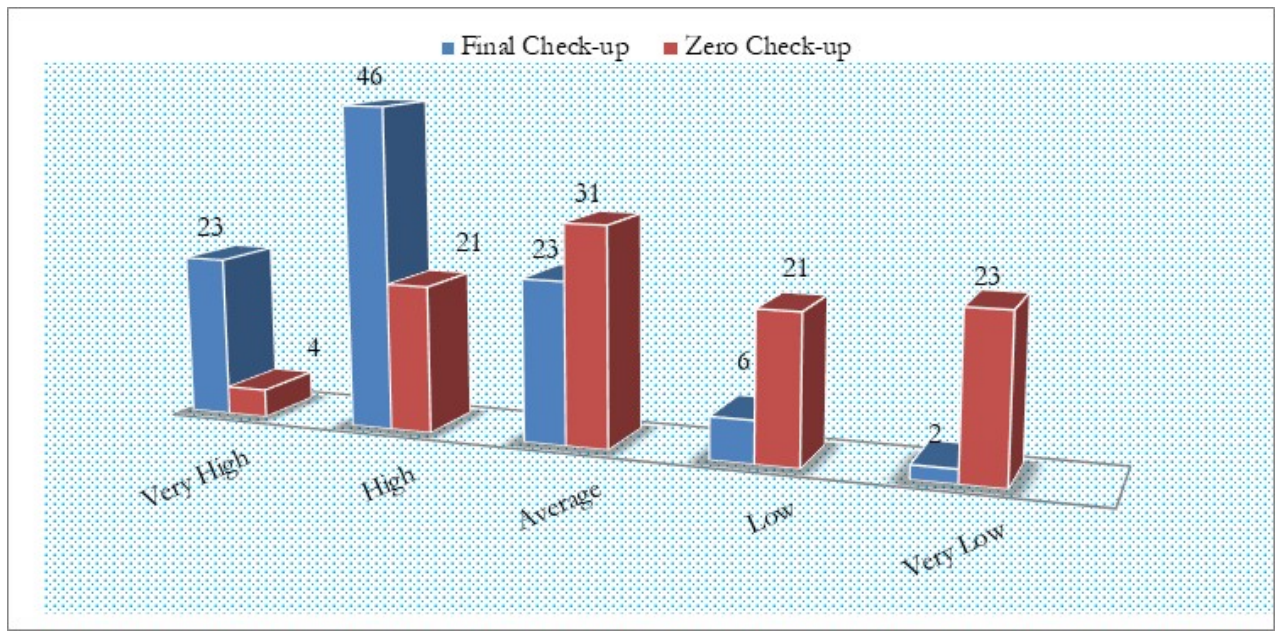

Figure 3: Comparison of the indicators in the development of the EG students' skills of choosing the tense forms of the verb in English before ("zero" check-up) and after the experiment ("final" check-up), in $\%$

The results of the questionnaire showed that answering the first question, "I can cooperate in group work," 1 (2\%) student chose the first answer, "I could not cooperate," which corresponded to the low fourth level of competence development. 10 (19\%) students responded that they "Cooperated sometimes, but let others do most of the work," such a response corresponded to the third level. 32 (62\%) students chose the third option "I cooperated most of the time but I could collaborate more," which corresponded to the second level and the rest of the students, $9(17 \%)$ preferred the fourth option "I was good in cooperation." "I contributed fully to the teamwork work," this option meant that these students had the first (highest) level of development of this competence. The answers to the second question of the self-assessment questionnaire, which concerned the competence to use a foreign language in communication with other team members, showed that $3(6 \%)$ students assessed themselves with the fourth level, 20 (38\%) with the third level, 17 (34\%) with the second and 12 (22\%) with the first level.

Questions from the third to the seventh detailed the development of individual communicative skills such as 3) the ability to defend their opinion, 4) explain their decisions, 5) ability to make suggestions to the group, 6) ability to ask others to explain things they do not understand and 7) the ability to perform the assigned task by communicating with their colleagues. The distribution of the answers to these questions according to the levels of development of the relevant competencies is shown in Table 4.

Table 4: The distribution of students in the EG by the levels of development of their communicative competencies

\begin{tabular}{|c|c|c|c|c|c|c|c|c|c|c|}
\hline \multirow{3}{*}{ Question № } & \multicolumn{8}{|c|}{ Levels of the development according to the options of answers } & \multirow{2}{*}{\multicolumn{2}{|c|}{ Total }} \\
\hline & \multicolumn{2}{|c|}{ The First } & \multicolumn{2}{|c|}{ The Second } & \multicolumn{2}{|c|}{ The Third } & \multicolumn{2}{|c|}{ The Fourth } & & \\
\hline & Person & $\%$ & Person & $\%$ & Person & $\%$ & Person & $\%$ & Person & $\%$ \\
\hline 3 & 8 & 15,0 & 30 & 59,0 & 10 & 19,0 & 4 & 7,0 & 52 & 100 \\
\hline 4 & 8 & 15,0 & 30 & 59,0 & 11 & 21,0 & 3 & 5,0 & 52 & 100 \\
\hline 5 & 11 & 20,0 & 32 & 63,0 & 8 & 15,0 & 1 & 2,0 & 52 & 100 \\
\hline 6 & 11 & 20,0 & 34 & 67,0 & 6 & 11,0 & 1 & 2,0 & $5^{2}$ & 100 \\
\hline 7 & 12 & 22,0 & 35 & 69,0 & 4 & 7,0 & 1 & 2,0 & 52 & 100 \\
\hline
\end{tabular}


Thus, the answers to question no. 3, "I can defend my opinions," distributed students in the following way. The first option of the answer, "I tried but I could not manage much," was chosen by 4 ( $7 \%)$ students, corresponding to the lowest (fourth) level of development of this competence. 10 or almost one-fifth of the students (19\%) chose the second option, "I managed but it was difficult," which gives grounds to refer them to the third level. The greatest number of responses (30 or 59\%) concerned the third response option, "I could generally do so. Sometimes I could not," which corresponded to the second level of development. Finally, the fourth response option, "I found this easy to do", which corresponded to the first (highest) level, was chosen by 5 (15\%) students.

Analyzing the data in Table 4, we can see that the distribution of answers to test question no. 4 "I can give reasons for my decisions," is identical to the third question of the third and fourth options. That is, the first and second levels of development of the ability to explain their decisions in a foreign language were recorded in $8(15 \%)$ and $30(59 \%)$ students, which in total is almost two-thirds of the group. A similar distribution can be observed in the answers to questions no. 5 "I can make suggestions to the group," and no. 6 "I can ask others to explain what I do not understand". In both questions, the first (highest) level was recorded for $11(20 \%)$ students. The low (fourth) level had one (2\%) student each. The proportions of second and third-level students varied slightly within the statistical margin of error. The responses to question no. 7 "I can complete the task which was set" test showed high test results with $12(22 \%)$ and 35 (69\%) students having the first and second levels, which is $91 \%$ of the group as a whole.

The next two test questions were directed at identifying the students' vocabulary (question eight) and developing the skills to correctly use the appropriate grammatical structures in statements (question no. 9). The test results for these questions are shown in Table 5.

Table 5: The distribution of students in the EG by the levels of their vocabulary development and mastery of grammatical structures

\begin{tabular}{|c|c|c|c|c|c|c|c|c|c|c|}
\hline \multirow{2}{*}{ Question № } & \multicolumn{6}{|c|}{ Levels of the development according to the options of answers } & \multicolumn{4}{c|}{ Total } \\
\cline { 2 - 11 } & \multicolumn{2}{|c|}{ The First } & \multicolumn{2}{c|}{ The Second } & \multicolumn{2}{c|}{ The Third } & \multicolumn{2}{c|}{ The Fourth } & \multicolumn{2}{c}{} \\
\cline { 2 - 11 } & Person & $\%$ & Person & $\%$ & Person & $\%$ & Person & $\%$ & Person & $\%$ \\
\hline 8 & 10 & 19,0 & 31 & 61,0 & 9 & 17,0 & 2 & 3,0 & 52 & 100 \\
\hline 9 & 7 & 13,0 & 30 & 59,0 & 12 & 23,0 & 3 & 5,0 & 52 & 100 \\
\hline
\end{tabular}

The data in Table 5 show that the performance of the test with a question no. 8 "I can use a range of words to express myself," is slightly higher than the similar data with a question no. 9 "I can use a range of grammatical structures to express myself". This may be due to the difficulties of understanding and the differences in grammatical forms of a foreign language as compared to the native language.

This raises the question of the impact of applying a cognitive linguistic approach to developing skills in choosing the tense forms of the verb in English on the self-assessment of skills to correctly use appropriate grammatical structures in the utterances.

To check this assumption, a correlational table was compiled by combining the data in Table 3 (the indicators of the development of the EG students' skills of choosing the tense forms of the verb in English, the final check-up) and Table 5 (answers to the ninth question about the development of skills to correctly use the appropriate grammatical structures in the utterances). For the convenience of calculations, let's combine the indicators of low and very low levels in Table 3. The summarized data are presented in Table 6 . 
Table 6: Correlation between the development of mastery the grammatical structures and the development of skills in choosing the tense forms of the verb among the EG students

\begin{tabular}{|l|c|c|c|c|c|}
\hline \multirow{2}{*}{$\begin{array}{l}\text { Levels of the development of skills in } \\
\text { choosing the tense form }\end{array}$} & \multicolumn{4}{|c|}{$\begin{array}{c}\text { Levels of the development of mastery of the } \\
\text { grammatical structures }\end{array}$} & \multirow{2}{*}{ Total: } \\
\cline { 2 - 5 } & The First & The Second & The Third & The Fourth & \\
\hline Very High & 7 & 5 & 0 & 0 & 12 \\
\hline High & 0 & 22 & 2 & 0 & 24 \\
\hline Average & 0 & 3 & 9 & 0 & 12 \\
\hline Low & 0 & 0 & 1 & 3 & 4 \\
\hline Total: & 7 & 30 & 12 & 3 & 52 \\
\hline
\end{tabular}

Tschuprow's coefficient calculated from the data in Table 6 is equal to $C=0,434$. The empirical value of the $\chi^{2}$ criterion is $\chi^{2}=88.256$, for the critical value $\chi_{2} \mathrm{cr}=21.666$ (at the significance level of $\mathrm{p}=0.01$ ). This leads to the conclusion that there is a correlation between the skills of choosing the tense forms of a verb formed by using the cognitive linguistic approach, on the one hand, and the levels of mastery of grammatical structures found in the simulation process, on the other hand.

\section{Discussion}

Analyzing the obtained results, it is worth paying attention to the fact that the method of simulation is quite widely used in the world practice of teaching foreign languages, as it has some didactic advantages in applying a foreign language to the future professional activity of students. In particular, we can agree with Angelini and García-Carbonell (2019a), who confirm that simulations are an effective tool for achieving sufficient foreign language proficiency for effective communication. At the same time, they combine simulations with the methodology of the "flipped classroom," where learning takes place on the Internet outside of class time, while traditional homework assignments are transferred to the classroom environment. Besides, it should be taken into account that simulation-based learning significantly contributes to students' progress in writing in English.

The results of our study are confirmed by the studies of Prabowo and Yuyun (2018), who also proved that the introduction of simulations contributes to the development of speaking skills of students learning English as a foreign language. As in our study, the authors used simulations that reproduced real-life relationships and a realistic environment. This improves the motivation of students by encouraging them for speaking activities.

The article by Michelson (2019) also draws attention, confirming the results of our study on the didactic effectiveness of simulation in teaching French as a foreign language to students. In contrast to our study, the author used a method of global simulation in which students played the roles of fictional characters living together in an apartment building in Paris, as well as performed written and oral tasks in the dialogic form in the discourse of imaginary and real current events.

Promising in terms of modernizing the method of simulations is the study of McKim (2017), who focuses on the integration of simulations, websites, social networks and mobile learning tools in foreign language learning.

It is worth noting that many authors use simulations, combining them with other approaches and methods of teaching students a foreign language. Thus, an essential aspect of our study was to establish the effectiveness of the cognitive linguistic approach in the development of skills in choosing the tense forms of the verb in English. A confirmation of the success of our revealed results can be found in the article by Takimoto (2020). His studies confirm the effectiveness of using the cognitive linguistic approach with the use of metaphors to teach different degrees of politeness in the learning of Japanese as a foreign language. However, this aspect (the use of metaphors) requires additional studies in terms of socio-cultural conditions and traditions.

We also consider the studies by Kaleta (2020) to be valuable for further study of the possibilities 
of the cognitive linguistic approach in learning a foreign language, which confirm the effectiveness of this approach in mastering such syntactic categories as infinitive and gerund in the learning of English by Polish students. Our attention was attracted by the study by Dolgova Jacobsen (2018), who proves the effectiveness of the cognitive linguistic approach in overcoming the complexity of conditional expressions in the process of teaching English to Polish students.

The article by El-Bouz (2016) presents the results of an empirical study proving the effectiveness of the cognitive linguistic approach to the learning of German modal aids by students learning German as a foreign language. Interestingly, this didactic concept was implemented by using animation. In our opinion, this fact needs further experimental testing.

It should also be agreed that simulations combined with role-playing have a positive effect in improving students' language skills. This is pointed out in the article by Razali and Ismail (2017). The test conducted by the authors showed that students were immersed in the plot of the simulation as if it was in reality. The authors claim that such lessons helped to expand the vocabulary and increased the students' level of fluent communication.

One of the types of simulations can be a paired simulation, which involves peer-to-peer learning in the process of reproducing different situations from future professional activities. That is the type of simulation is described in their article by Rokhayani et al. (2017). Analyzing the results of their studies, they note that the combination of simulations with role-playing games in paired learning provides the development of their speech competence in English, reduces the psychological distance between teachers and students, forms confidence and professional motivation.

\section{Conclusion}

The results of our experimental study lead us to the conclusion that the application of the method of simulations in combination with the cognitive linguistic approach provides high efficiency of teaching students a foreign language.

To experimentally test the suggested methodology, an experimental group was formed (52 students of the specialization "Management"), in which teaching a foreign language during the semester of the 2019-2020 academic year was carried out using simulations, as well as the cognitive linguistic approach to the development of English grammar skills. The effectiveness of the method was established by comparing it with the control group, in which foreign language classes were conducted according to the traditional methodology.

According to the results of the experiment the proportion of experimental group students with a high and sufficient level of success in learning a foreign language exceeded more than twice the same indicator in the control group. Thanks to the application of the cognitive linguistic approach a tangible improvement in the development of the skills of choosing the tense forms of the verb in English was achieved. The total proportion of students with very high, high and average levels of development of these skills increased by $36 \%$. Also, using correlation analysis, the influence of the development of skills in choosing the tense forms of the verb on the development of skills in using the grammatical structures revealed in the process of the simulation was recorded. The statistical significance of the results of the study was determined by using Pearson's $\chi^{2}$ criterion.

Thanks to the cognitive linguistic approach and the method of simulations, the language competencies of a business foreign language were developed such as the ability to defend one's opinion, to explain one's decisions, the ability to make suggestions to the group, to ask other team members to explain things they do not understand, to complete the set task by communicating with colleagues, to develop vocabulary and the ability to use grammar structures to properly express one's thoughts.

At the same time, during the study, a range of problems was recorded in students who had a low level of language competence (passive participation in simulations, inability to cooperate in group work and to use a foreign language when communicating with other team members. Thus, the problems of the passivity of individual students regarding their participation in simulations, inability to use a foreign language in group work require further study. The substantiation of the teacher's role in the 
application of the cognitive linguistic approach and the method of simulations in teaching students a foreign language in higher educational institutions reveals a promising direction.

The results of the study can be used in teaching students a foreign language in the institutions of higher and secondary education, as well as in the system of postgraduate education.

\section{References}

Angelini, M. L. \& García-Carbonell, A. (2019a). Developing English speaking skills through simulation-based instruction. English Language Teaching, 19(2), 3-20. http://www.tewtjournal.org

Angelini, M. L. \& García-Carbonell, A. (2019b). Enhancing students' written production in English through flipped lessons and simulations. International Journal of Educational Technology in Higher Education. https://doi.org/10.1186/s41239-019-0131-8

Beames, S. \& Brown, M. (2016). Adventurous learning. New York: Routledge. https://doi.org/10.4324/9781315736488

Chergui, K. (2016). The effect of using simulation activities on developing Algerian EFL students' speaking and listening proficiency. Sciences Humaines, B(46), 207-222.

Dolgova Jacobsen, N. (2018). The best of both worlds: Combining cognitive linguistics and pedagogic tasks to teach English conditionals. Applied Linguistics, 39(5), 668-693. https://doi.org/10.1093/applin/amw030

El-Bouz, K. (2016). Animation of grammar - Interplay of cognitive linguistics and multimedia learning: The example of German modal auxiliaries. Yearbook of the German Cognitive Linguistics Association, 4(1), 135-152. https://doi.org/10.1515/gcla-2016-oo10

European Commission (2020). Education and Training: European Credit Transfer and Accumulation System (ECTS). https://ec.europa.eu/education/resources-and-tools/european-credit-transfer-and-accumulation-systemects_en

Hawk, T. F. \& Shah, A. J. (2007). Using learning style instruments to enhance student learning. Decision Sciences Journal of Innovative Education. 5(1), 1-19.

Holitsynskyi, Yu. B. \& Holitsynska, N. A. (2019). Hramatyka [Grammar]. Kyiv: Arii. [in Ukrainian].

Jones, K. (2013). Simulations: A handbook for teachers and trainers. London: Routledge.

Kaleta, A. (2020). 'The infinitive or the gerund? Cognitive linguistics in teaching English post-verbal complementation'. In G. Drożdż \& B. Taraszka-Drożdż (Eds.), Foreign Language Pedagogy in the Light of Cognitive Linguistics Research. Second Language Learning and Teaching. Cham: Springer. https://doi.org/10.1007/978-3-030-58775-8_4

Kolb, D. A. \& Kolb A. Y. (2017). The Experiential Educator: Principles and Practices of Experiential Learning. Experience-Based Learning Systems.

Kravchenko, A. V. (2013). Kognitivnaya grammatika na uroke angliyskogo ili kak oblegchit zhizn russkim studentam [Cognitive grammar in an English lesson or how to make life easier for Russian students]. MGIMO Review of International Relations, 6, 83-89. [in Russian].

Li, Y. (2019). Cognitive linguistic approach to teaching English phrasal verbs: Experimental evidence on «V+down/up» Constructions 4th International Conference on Social Science and Contemporary Humanity Development (SSCHD). Advance in Social Science, Education and Humanities Research, 281, 220-224.

Li, Y., Medwell, J., Wray, D., Wang, L. \& Liu, X. (2016). Learning styles: A review of validity and usefulness. Journal of Education and Training Studies, 4(10).

Lutfi, A. A., Sutopo, D. \& Rukmini, D. (2018). The effectiveness of simulation and role-play in teaching speaking for students with different levels of motivation. English Education Journal, 8(4), 489-498. http://journal.unnes.ac.id/sju/index.php/eej

McKim, K. (2017). Flipping global simulations: Global simulations in the digital era. Recherche et pratiques pédagogiques en langues de spécialité, 36(2). http://journals.openedition.org/apliut/575o

Methods. (2013). Simulation: A language learning tactic. https://www.languages.dk/archive/Methods/manuals /Simulation/simultation\%2oUK.pdf

Michelson, K. (2019). Global simulation as a mediating tool for teaching and learning language and culture as discourse. Foreign language Annals, 52(2), 284-313.

Odo, C. R. \& Odo, A. I. (2016). Effect of simulation on students' interest in the programming language in Secondary Schools in Enugu Education Zone of Nigeria. International Journal of Information and Education Technology, 6(6), $477-480$.

Oskina, S. D. (2017). Simulyatsiya kak metod interaktivnogo podkhoda k obucheniyu angliyskomu yazyku v neyazykovom vuze [Simulation as a method of an interactive approach to teaching English in a non-linguistic university]. Psychopedagogy in Law Enforcement, 1(68), 75-78. [in Russian]. 
Prabowo, C. A \& Yuyun, Y. (2018). Teaching speaking using simulation to the eighth grade students of junior high school. Journal of English Language and Language Teaching, 2(1), 33-38.

Razali, N. N. F. M. \& Ismail, R. (2017). The use of simulation and role-play in enhancing speaking skills in learning English language. Journal of Education and Social Sciences, 6(2), 72-78.

Rokhayani, R. A., Nurcahyo, A. D., Rukmini, D. \& Sofwan, A. (2017). Peer teaching as a simulation for communicative classroom English. A Journal of Culture, English Language Teaching and Literature, 17(1), 103-116.

Sharifi, A., Ghanizadeh, A. \& Jahedizadeh, S. (2017). The effect of simulation on middle school students' perception of classroom activities and their foreign language achievement. IEJEE, 9(3), 668-68o.

Shcherbakova, O. V. (2018). Tekhnologiya globalnoy simulyatsii kak effektivnyy metod formirovaniya lingvosotsiokulturnoy kompetentsii. Istoriya vozniknoveniya. kontsept. struktura (na primere simulyatsii Debuze «Zhiloy dom») [Global simulation technology as an effective method for the formation of linguistic socio-cultural competence. History of origin. concept. structure (on the example of the Debuze simulation “Dwelling house")]. Pedagogy. Theory E Practice, 2(10), 67-70. https://doi.org/10.30853/pedagogy.2018-2.15 [in Russian].

Takimoto, M. (2020). Investigating the effects of cognitive linguistic approach in developing EFL learners' pragmatic proficiency. System. An International Journal of Educational Technology and Applied Linguistics, 89, 102213. https://doi.org/10.1016/j.system.2020.102213

Uguma, V. U. \& Obiekezie, E. O. (2018). Simulation and dramatization teaching methods and students' academic performance in English language. Advances in Multidisciplinary E Scientific Research Journal, 4(2), 1-10.

Vlachopoulos, D. \& Makri A. (2017). The effect of games and simulations on higher education: A systematic literature review. International Journal of Educational Technology in Higher Education, 14(22), 1-33. https://doi.org/10.1186/s41239-017-0062-1

\section{Appendix}

Table 7: Self-Assessment Form Student*

\begin{tabular}{|c|c|c|c|c|c|c|}
\hline \multicolumn{2}{|c|}{ GENERAL } & \multirow{2}{*}{\begin{tabular}{|l|}
1 \\
I could not co- \\
operate
\end{tabular}} & \multirow{2}{*}{\begin{tabular}{|l|}
2 \\
I co-operated \\
sometimes, but let \\
others do most of the \\
work
\end{tabular}} & \multirow{2}{*}{\begin{tabular}{|l}
3 \\
I co-operated most of \\
the time, but could co- \\
operate more
\end{tabular}} & \multirow{2}{*}{\begin{tabular}{|l}
4 \\
I found I was good at co- \\
operation. I contributed \\
fully to the teamwork
\end{tabular}} & \multirow{2}{*}{\begin{tabular}{|l|} 
Score \\
\end{tabular}} \\
\hline 1 & $\begin{array}{l}\text { I can co-operate in group } \\
\text { work }\end{array}$ & & & & & \\
\hline 2 & $\begin{array}{l}\text { I can use the } \mathrm{TL}^{* *} \text { when } \\
\text { speaking to others in my } \\
\text { team }\end{array}$ & $\begin{array}{l}\text { I could not } \\
\text { use TL much }\end{array}$ & $\begin{array}{l}\text { I used TL, } \\
\text { but found it } \\
\text { difficult }\end{array}$ & $\begin{array}{l}\text { I used TL, but there } \\
\text { were some things I } \\
\text { could not say }\end{array}$ & $\begin{array}{l}\text { I used TL and found it easy } \\
\text { to use. Was quite fluent }\end{array}$ & \\
\hline 3 & $\begin{array}{l}\text { I can manage to defend } \\
\text { my } \\
\text { opinions }\end{array}$ & $\begin{array}{l}\text { I tried, but } \\
\text { I could not } \\
\text { manage much }\end{array}$ & $\begin{array}{l}\text { I managed, } \\
\text { but it was } \\
\text { difficult }\end{array}$ & $\begin{array}{l}\text { I could generally do so. } \\
\text { Sometimes I could not }\end{array}$ & $\begin{array}{l}\text { I found this } \\
\text { easy to do }\end{array}$ & \\
\hline 4 & $\begin{array}{l}\text { I can give reasons for my } \\
\text { decisions }\end{array}$ & $\begin{array}{l}\text { I tried, but } \\
\text { I could not } \\
\text { manage much }\end{array}$ & $\begin{array}{l}\text { I managed, } \\
\text { but it was } \\
\text { difficult }\end{array}$ & $\begin{array}{l}\text { I could generally do so. } \\
\text { Sometimes I could not }\end{array}$ & $\begin{array}{l}\text { I found this } \\
\text { easy to do }\end{array}$ & \\
\hline 5 & $\begin{array}{l}\text { I can make } \\
\text { suggestions to the group }\end{array}$ & $\begin{array}{l}\text { I tried, but } \\
\text { I could not } \\
\text { manage much }\end{array}$ & $\begin{array}{l}\text { I managed, } \\
\text { but it was } \\
\text { difficult }\end{array}$ & $\begin{array}{l}\text { I could generally do so. } \\
\text { Sometimes } \\
\text { I could not }\end{array}$ & $\begin{array}{l}\text { I found this } \\
\text { easy to do }\end{array}$ & \\
\hline 6 & $\begin{array}{l}\text { I can ask others to } \\
\text { explain what I do not } \\
\text { understand }\end{array}$ & $\begin{array}{l}\text { I tried, but } \\
\text { I could not } \\
\text { manage much }\end{array}$ & $\begin{array}{l}\text { I managed, } \\
\text { but it was } \\
\text { difficult }\end{array}$ & $\begin{array}{l}\text { I could generally do so. } \\
\text { Sometimes } \\
\text { I could not }\end{array}$ & $\begin{array}{l}\text { I found this } \\
\text { easy to do }\end{array}$ & \\
\hline 7 & $\begin{array}{l}\text { I can complete } \\
\text { the task which } \\
\text { was set }\end{array}$ & $\begin{array}{l}\text { I tried, but } \\
\text { I could not } \\
\text { manage much }\end{array}$ & $\begin{array}{l}\text { I managed, } \\
\text { but it was } \\
\text { difficult }\end{array}$ & $\begin{array}{l}\text { I could generally do so. } \\
\text { Sometimes } \\
\text { I could not }\end{array}$ & $\begin{array}{l}\text { I found this } \\
\text { easy to do }\end{array}$ & \\
\hline 8 & $\begin{array}{l}\text { I can use a range of } \\
\text { words to express myself }\end{array}$ & $\begin{array}{l}\text { I have very } \\
\text { few words in } \\
\text { my vocabulary }\end{array}$ & $\begin{array}{l}\text { I managed but } \\
\text { I need a lot } \\
\text { more vocabulary }\end{array}$ & $\begin{array}{l}\text { Generally, I managed, } \\
\text { but there were some } \\
\text { words I didn't know }\end{array}$ & $\begin{array}{l}\text { I found I knew most of the } \\
\text { words. It was easy }\end{array}$ & \\
\hline 9 & $\begin{array}{l}\text { I can use a range of } \\
\text { grammatical structures } \\
\text { to express myself }\end{array}$ & $\begin{array}{l}\text { I use only } \\
\text { simple } \\
\text { sentences }\end{array}$ & $\begin{array}{l}\text { I try and use longer } \\
\text { sentences, but it's } \\
\text { difficult }\end{array}$ & $\begin{array}{l}\text { I generally manage, but I } \\
\text { need to learn more }\end{array}$ & $\begin{array}{l}\text { I feel confident } \\
\text { using a variety } \\
\text { of sentences }\end{array}$ & \\
\hline \multicolumn{6}{|c|}{ OTAL } & \\
\hline
\end{tabular}

${ }^{*}$ Methods (2013, pp. 31-32).; ** TL = Target Language 